\title{
PROFIL TINGKAT KENYAMANAN UDARA DAN HUBUNGANNYA DENGAN HARI HUJAN DI BUKIT KOTOTABANG TAHUN 2010-2018
}

\section{PROFILE OF AIR COMFORT LEVELS AND THE RELATIONSHIP WITH THE RAIN DAYS IN BUKIT KOTOTABANG DURING 2010-2018}

\author{
Andi Sulistiyono ${ }^{*}$,Rendi Septa Davi² dan Ikhsan Buyung Arifin ${ }^{3}$ \\ 1-3Stasiun Pemantau Atmosfer Global Bukit Kototabang \\ *Email: sulist_klim@yahoo.com \\ Naskah masuk: 24 Mei 2020, Naskah diperbaiki: 15 Juli 2020, Naskah diterima: 25 Juli 2020
}

\begin{abstract}
ABSTRAK
ABSTRACT

Adanya perubahan lingkungan sekitar stasiun GAW Bukit Kototabang disinyalir menyebabkan perubahan parameter cuaca yang berpengaruh terhadap tingkat kenyamanan. Penelitian ini bertujuan untuk mengetahui tingkat kenyamanan di stasiun GAW Bukit Kototabang serta hubungannya dengan hari hujan. Studi tingkat kenyamanan ini menggunakan indeks Humidex yang dihasilkan dari data AAWS dan F.klim di stasiun GAW Bukit Kototabang dari tahun 2010 hingga 2018 yang dibagi dalam beberapa periode waktu. Selanjutnya hubungan antara hari hujan dengan tingkat kenyaman menggunakan metode korelasi. Dari hasil tersebut didapatkan bahwa tidak terjadi kondisi "Tidak Nyaman" selama periode tahun 20102018. Kondisi nyaman terjadi pada periode waktu pagi dan malam hari sedangkan pada periode waktu siang hari pada kondisi "Kurang Nyaman. Persentase jumlah hari "Nyaman" terbesar terjadi pada bulan Juli dan Januari. Periode tahun 2013-2015 merupakan persentase jumlah hari "Nyaman" paling sedikit jika dibandingkan dengan tahun sebelum (2010-2013) dan tahun sesudahnya (20162018). Tidak adanya penurunan persentase "Nyaman" pada tahun 2017-2018 terhadap tahun-tahun sebelumnya maka disinyalir belum ada pengaruh tingkat kenyamanan tahun 20172018 terhadap perubahan di lingkungan sekitar

The change of the environment around the station of Global Atmospheric Watch Bukit Kototabang allegedly causing change in the weather factors that affect the level of discomfort. This study aims to determine the level of comfort at Bukit Kototabang GAW station and its relationship to rainy days. Study of discomfort level using calculation of Humidex was conducted using diurnal AAWS data and Fklim data resulted that does not occur "Uncomfortable" conditions for the period 20102018. The conditions are "Comfortable" in the morning and evening periods while in the afternoon the conditions are " Less Comfortable". The largest percentage of " Comfortable " days occur in July and January. The percentage of " Comfortable "days for 2013-2015 is lower compared to the year before (2010-2013) and the year after (20162018). There is no decrease in the percentage of "Comfortable" in 2017-2018 against previous years, then it is considered that there is no effect of comfort levels for 2017-2018 on changes in the environment around the station.. The correlation of "Comfortable" days to monthly rainy days during study period is 0.69 , but the number of monthly rainy days (rain events) is less appreciative of the number of days of "Comfortable" conditions at GAW Bukit Kototabang Station.
\end{abstract} stasiun. Hubungan antara jumlah hari "Nyaman" terhadap jumlah hari hujan bulanan di Stasiun GAW Bukit Kototabang memiliki korelasi positif yang kuat.

Kata kunci: Humidex, hari hujan, tingkat kenyamanan, GAW Bukit Kototabang
Keywords: Humidex, rainy days, air comfort level, GAW Bukit Kototabang 


\section{Pendahuluan}

Stasiun Global Atmosfer Watch (GAW) dibangun dan dipilih lokasi berdasarkan tujuan dan fungsinya. Terletak di Sumatera Barat $\left(0^{\circ}\right.$ $12^{\prime} 07^{\prime \prime} \mathrm{LS}-100^{\circ} 19^{\prime} 05^{\prime \prime} \mathrm{BT}$ ) berada pada area terpencil pada ketinggian $864,5 \mathrm{~m}$ di atas permukaan laut dan $40 \mathrm{~km}$ dari garis pantai bagian Barat Sumatera. Wilayah dengan vegetasi yang sebagian besar berupa hutan tropis dan berada pada topografi perbukitan menjadikan keadaan lingkungan senantiasa segar dan sejuk.

Prakirakan percepatan perubahan lingkungan sekitar stasiun adalah lambat, merupakan alasan bahwa stasiun GAW Bukit Kototabang mempunyai tugas dan fungsi untuk mengadakan pengukuran kualitas udara dan sekaligus sebagai stasiun referensi udara bersih. Sehingga daripada itu maka Stasiun GAW Bukit Kototabang merupakan salah satu stasiun di daerah ekuatorial yang penting dalam program pengamatan atmosfer secara global untuk pengukuran kondisi atmosfer dan kualitas udara.

Seiring dengan berjalannya waktu, perubahan juga terjadi pada kondisi lingkungan sekitar wilayah stasiun GAW Bukit Kototabang. Perubahan lebih dikarenakan kegiatan masyarakat sekitar yang memanfaatkan hutan untuk diambil kayunya serta aktifitas berkebun. Adanya aktifitas dari masyarakat menjadikan vegetasi alami di sekitar bukit kototabang berkurang.

Adanya perubahan terhadap lingkungan, baik secara langsung maupun tidak langsung akan turut menyebabkan perubahan terhadap keadaan atmosfer dalam hal ini kondisi udara yang dirasakan. Hal ini karena atmosfer merupakan manisfestasi dari parameter dan unsur-unsur penyusunnya. Perubahan unsur iklim dapat terjadi pada: suhu udara, penerimaan radiasi matahari, kecepatan angin, dan perawanan [1]. Dari unsur-unsur tersebut, yang dapat dirasakan secara langsung perubahannya adalah suhu udara dan kelembaban udara.

Kenyamanan termis sangat dibutuhkan tubuh agar manusia dapat beraktifitas dengan baik [2]. Dalam kenyamanan termis, manusia merasakan sensasi panas atau dingin sebagai wujud respon dari sensor perasa yang terdapat pada permukaan kulit terhadap perubahan suhu udara [3]. IImu kenyamanan termis hanya membatasi pada kondisi udara tidak ekstrem (moderate thermal environment) dimana manusia masih dapat mengantisipasi dirinya terhadap perubahan suhu udara di sekitarnya [4].

Pengaruh faktor cuaca terhadap kenyaman yang dirasakan dapat diidentifikasi dengan penghitungan suatu indek kenyaman. Beberapa rumusan dan penelitian ilmiah tentang indek kenyamanan telah digunakan diberbagai tempat untuk mengkaji keadaan tingkat kenyamanan berdasarkan pengaruh keadaan parameter cuaca masing-masing wilayah di Indonesia, diantaranya Indeks Panas Humidex di Kota Tanjung Pinang dengan hasil penelitian menunjukkan rata-rata Humidex bulanan di wilayah Kota Tanjung Pinang berkisar antara $32.6-34.0^{\circ} \mathrm{C}$. Artinya tren indek kenyamanannya mengalami peningkatan. Tren peningkatan nilai indeks panas di wilayah Kota Tanjung Pinang disebabkan akibat semakin meningkatnya perubahan penggunaan lahan menjadi lahan terbangun, galaknya program urbanisasi, dan maraknya penggunaan kendaraan bermotor. [4]

Selanjutnya ada penelitian Indeks Panas Humidex di DKI Jakarta Hasil menunjukkan rata-rata Humidex bulanan di wilayah DKI Jakarta berkisar antara 36,1 s.d. $39,5^{\circ} \mathrm{C}$ dan hubungan antara kecepatan angin dengan Humidex adalah menurunkan nilai Humidex yang berdampak pada peningkatan rasa nyaman termis. Sedangkan jumlah kendaraan bermotor menunjukkan kecenderungan peningkatan secara eksponensial dan berpengaruh terhadap semakin menurunnya tingkat kenyamanan termis [5]

Penelitian Indeks Panas THI di DKI Jakarta dengan kesimpulan yaitu tingkat kenyamanan menunjukkan semakin ke tengah kota semakin besar persentase tidak nyaman. Selama periode tersebut terjadi kecenderungan peningkatan indeks $\mathrm{THI}$ dengan signifikansi > $50 \%$ menunjukkan tingkat kenyamanan di DKI Jakarta cenderung semakin tidak nyaman. [6]. Dari ketiga penelitian diatas masing-masing persamaan indeks kenyamanan tersebut memiliki batas kenyamanan yang berbedabeda.

Pola hujan equatorial [15] dengan topografi stasiun yang berbukit beserta adanya aktifitas manusia ditengarai telah terjadi perubahan kondisi lingkungan di sekitar stasiun. Hal ini menarik perhatian bagi penulis untuk mengetahui tingkat perubahan lingkungan dengan penghitungan suatu metode tingkat kenyamanan udara berdasar periode waktu. 
Adanya hujan akan berpengaruh terhadap parameter cuaca dalam hal ini suhu dan kelembaban udara. Oleh karena itu hujan dalam hal ini jumlah hari hujan akan dianalisis pengaruh (hubungan) terhadap tingkat kenyamanan yang terjadi.

Penelitian ini bertujuan untuk mengetahui bagaimana tingkat kenyamanan di Stasiun GAW Bukit Kototabang serta hubungan hari hujan dengan tingkat kenyamanan tersebut. Analisis tingkat kenyamanan tahunan diharapkan dapat memberikan informasi tentang adanya dugaan perubahan lingkungan yang mempengaruhi parameter cuaca di stasiun GAW Bukit Kototabang.

\section{Metode Penelitian}

Metode yang digunakan untuk mengetahui tingkat kenyamanan pada penelitian ini adalah Metode Humidex Index. Humidex didefinisikan sebagai suhu pada udara yang relatif kering (tekanan uap kurang dari $10 \mathrm{hPa}$ ) yang memiliki pengaruh kenyamanan pada manusia yang sama dengan udara dengan suhu dan kelembaban yang diukur secara aktual maupun yang diramalkan [7].

Perhitungan Humidex menggunakan rumus Lally and Watson (1960) [8]; Masterson and Richardson (1979) [9] sebagai berikut:

$$
\begin{aligned}
& \text { Humidex }=T+\frac{5}{9}(e-10) \\
& e=6,112 \times 10^{\left(\frac{7,5 T}{(237,7+T}\right)} \times \frac{R H}{100}
\end{aligned}
$$

dengan:

$$
\begin{array}{ll}
\text { Humidex : Indeks panas }\left({ }^{\circ} \mathrm{C}\right) \\
\mathrm{T} & : \text { Suhu udara rata-rata }\left({ }^{\circ} \mathrm{C}\right) \\
\mathrm{RH} & : \text { Kelembaban relatif rata-rata }(\%)
\end{array}
$$

Data unsur cuaca yang digunakan untuk penghitungan indek kenyamanan Humidex adalah data rata-rata harian yang bersumber dari laporan F.Klim71 dan data diurnal (tiap jam) dari hasil pengukuran AAWS yang ada di taman alat stasiun GAW Bukit Kototabang. Untuk mengetahui tingkat kenyamanan bulanan dan tahunan digunakan data klimatologi ( $F$. Klim-71) Stasiun GAW Bukit Kototabang tahun 2010-2018. Karena ketersediaan data unsur

\begin{tabular}{|c|c|}
\hline $\begin{array}{l}\text { Indeks } \\
\text { Humidex }\end{array}$ & Kategori Interpretasi \\
\hline$\leq 29 \circ \mathrm{C}$ & Nyaman \\
\hline $30-34^{\circ} \mathrm{C}$ & Perasaan sedikit tidak nyaman \\
\hline $35-39^{\circ} \mathrm{C}$ & Perasaaan tidak nyaman \\
\hline $40-45^{\circ} \mathrm{C}$ & $\begin{array}{l}\text { Perasaan sangat tidak nyaman } \\
\text { akibat panas hingga } \\
\text { menimbulkan rasa tersengat } \\
\text { akibat panas }\end{array}$ \\
\hline $46-53^{\circ} \mathrm{C}$ & $\begin{array}{l}\text { Perasaan sangat tidak nyaman } \\
\text { dan hampir dapat } \\
\text { menyebabkan penyakit akibat } \\
\text { serangan panas }\end{array}$ \\
\hline$\geq 54{ }^{\circ} \mathrm{C}$ & Kematian akibat panas \\
\hline
\end{tabular}
cuaca diurnal (tiap jam) untuk instrumen AWS maka data tingkat kenyaman periode diurnal (tiap jam) digunakan data tahun 2017-2018.
Tabel 1. Indeks Interpretasi Humidex [10]

Selain data suhu dan kelembaban, akan digunakan juga data hari hujan untuk mengetahui hubungan (korelasi) antara indek kenyamanan terhadap jumlah hari hujan. Pada kesempatan ini, hari hujan didefinisikan sebagai hujan yang tertakar lebih besar dari 1 $\mathrm{mm}$ [11].

Pada studi ini akan memberikan informasi tentang kenyamanan termal di Stasiun GAW Bukit Kototabang. Kenyamanan termal tersebut akan disajikan berdasarkan pembagian waktu periode diurnal (pagi-siang-malam), periode bulanan dan tahunan sehingga dari sini akan diketahui persentase jumlah terbesar keadaan kenyamanan pada suatu periode waktu tersebut.

Mula-mula setelah didapatkan nilai indek kenyamanan secara diurnal dilakukan pembagian waktu periode diurnal yaitu pagi, siang dan malam. Pembagian waktu diurnal mengacu pada De Eka Sas [12] yang mengemukakan bahwa waktu pagi dimulai pukul 05.00 s/d 10.00 WIB, waktu siang berlangsung mulai pukul $10.00 \mathrm{~s} / \mathrm{d} 15.00$ WIB dan malam $19.00 \mathrm{~s} / \mathrm{d} \quad 00.00$ WIB. Indek kenyamanan periode waktu diurnal dihitung dari rata-rata indek tiap jam menurut pembagian periode waktu diurnal pagi, siang dan malam. 
$x_{\text {periode diurnal }}=\frac{x_{1}+x_{2}+x_{3}+\cdots x_{n}}{\mathrm{n}}$

Dengan :

Xeriode diurnal: rata-rata indeks kenyamanan pada periode diurnal

$X_{1}, X_{2}, \ldots . . X_{n}$ : data indek kenyamanan tiap jam periode waktu diurnal

$\mathrm{n}$

: jam periode waktu diurnal tiap bulan

Analisis kenyamanan bulanan didapatkan dari jumlah hari pada keadaan "Nyaman" dan "Kurang Nyaman" pada setiap bulan. Dari sini dilanjutkan penghitungan persentase kenyamanan bulanan setiap tahun.

$$
U_{\text {Mouthx }}=\left(\frac{\sum_{k=1}^{k=n}}{n} U_{c}\right) x 100 \%
$$

Dengan :

$\bar{U}_{\text {Mouth } \mathrm{x}}$ : Persentase "Nyaman" bulan $\mathrm{x}$

Uc : Indek pada Kondisi "Nyaman"

k : Tanggal

$\mathrm{n} \quad$ : jumlah hari sebulan

Analisis tahunan dilakukan dengan pengelompokan tingkat kenyamanan tahun 2010 - 2018 menjadi 3 kelompok tahun meliputi tahun 2010 s/d 2012, tahun 2013 s/d 2015 dan tahun 2016 s/d 2018. Selanjutnya dibuat persentase tingkat kenyamanan pada periode tahun untuk mengetahui pola dan informasi terkait dengan kondisi kenyamanan yang terjadi di stasiun GAW Bukit kototabang pada tahun tersebut.

Analisis secara deskriptif terhadap grafik tingkat kenyamanan periode diurnal, bulanan dan periode tahunan dilakukan untuk mengetahui pola dan informasi terkait dengan kondisi kenyamanan yang terjadi di stasiun GAW Bukit Kototabang.

Analisis tahunan dan bulanan untuk mengetahui kondisi umum keadaan kenyamanan udara seiring dengan perubahan keadaan lingkungan sekitar stasiun dengan memfokuskan perhatian pada tahun 2017 dan 2018 dengan dibandingkan dengan tahun yang lampau (2010-2012).

Selain data suhu dan kelembaban, akan digunakan juga data hari hujan untuk mengetahui hubungan (korelasi) antara indek kenyamanan terhadap jumlah hari hujan. Pada kesempatan ini, hari hujan didefinisikan sebagai hujan yang tertakar lebih besar dari $1 \mathrm{~mm}$ [12]
Adanya hujan akan meningkatkan kelembaban dan suhu menjadi lebih rendah. Semakin banyak hari hujan maka suhu dan kelembaban akan mengalami perubahan yang akan mempengaruhi nilai tingkat kenyamanan.

Uji koefisien korelasi yang digunakan adalah korelasi linier Pearson untuk mengetahui kuat/tidaknya hubungan antara indek kenyamanan harian terhadap kejadian (hari) hujan. Kriteria nilai korelasi mengikuti tabel 2 di bawah ini.

Tabel 2. Kriteria nilai korelasi [13]

\begin{tabular}{l|l}
\hline Interval Hobungan & Tingkat Hobungan \\
\hline 0 & Tidak ada kocelasi antara dua variabel \\
\hline$>0=0,25$ & Korelasi sangat lemah \\
\hline$>0,25-0,5$ & Korelasi cukup \\
\hline$>0,5-0,75$ & Korelasi kuat \\
\hline$>0,75-0,99$ & Korelasi sangat Kuat \\
\hline 1 & Korelasi sempuma \\
\hline
\end{tabular}

\section{Hasil dan Pembahasan}

Distribusi tingkat kenyamanan periode waktu diurnal (pagi, siang dan malam). Penghitungan indek kenyamanan Humidex pada periode tahun 2017-2018 data diurnal AAWS diketahui bahwa tidak terjadi kondisi "Tidak Nyaman" di stasiun GAW Bukit Kototabang.

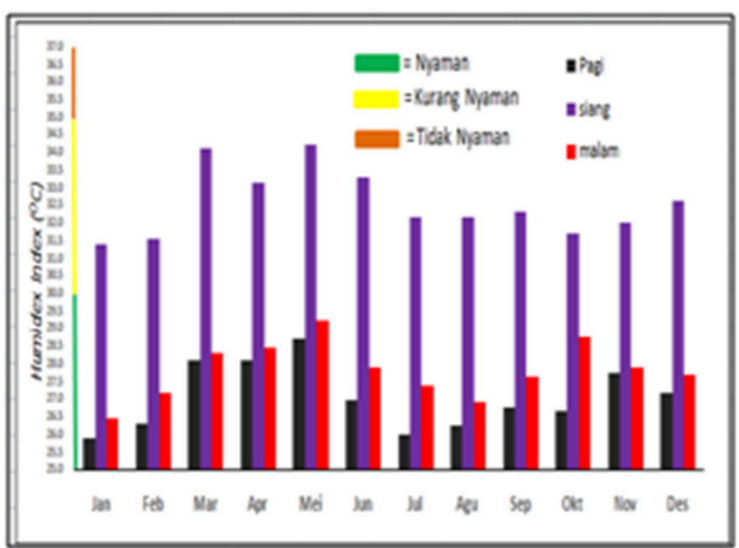

Gambar 1. Grafik diurnal tingkat kenyamanan bulanan periode 2017-2018 
Tingkat kenyamanan Humidex seperti pada gambar 1 menunjukkan pada waktu pagi dan malam hari berada pada kondisi "Nyaman" sedangkan untuk siang hari secara umum pada kondisi "Kurang Nyaman". Selisih suhu Humidex antara pagi hari dan malam hari berkisar antara $4^{\circ} \mathrm{C}-6^{\circ} \mathrm{C}$.

Keadaan "Nyaman" diurnal pada pagi dan malam hari periode bulanan membentuk 2 buah pola puncak. Kondisi nyaman terjadi JanuariFebruari dan Juli-September (lihat gambar 1 pada periode waktu pagi dan malam), sedangkan pada indek "Kurang Nyaman" membentuk 1 puncak yaitu bulan Mei (lihat gambar 1 pada periode waktu siang).

Perhitungan Humidex berdasarkan periode waktu siang-malam pernah dilakukan oleh Trinah Wati dan Riri Indriani Nasution [5] menunjukkan suhu Humidex di lokasi Jabodetabek pada malam hari lebih rendah lebih rendah dari siang hari dengan selisih antara $2{ }^{\circ} \mathrm{C} \mathrm{s} / \mathrm{d} 4{ }^{\circ} \mathrm{C}$.

Baik pada Jabodetabek maupun di lingkungan stasiun GAW Bukit Kototabang suhu Humidex pada malam hari lebih rendah dari siang hari. Topografi stasiun GAW Bukit Kototabang yang berada di perbukitan menjadikan gradien suhu diurnal harian lebih tinggi dari wilayah perkotaan (Jabodetabek)

Persentase kenyamanan bulanan periode 2010-2018. Dengan menggunakan data Fklim 71 periode tahun 2010-2018 Stasiun GAW Bukit Kototabang didapatkan kondisi kenyamanan harian. Dari hasil penghitungan indek kenyamanan Humidex, tidak terjadi kondisi "Tidak Nyaman" secara harian selama periode tahun 2010-2018.

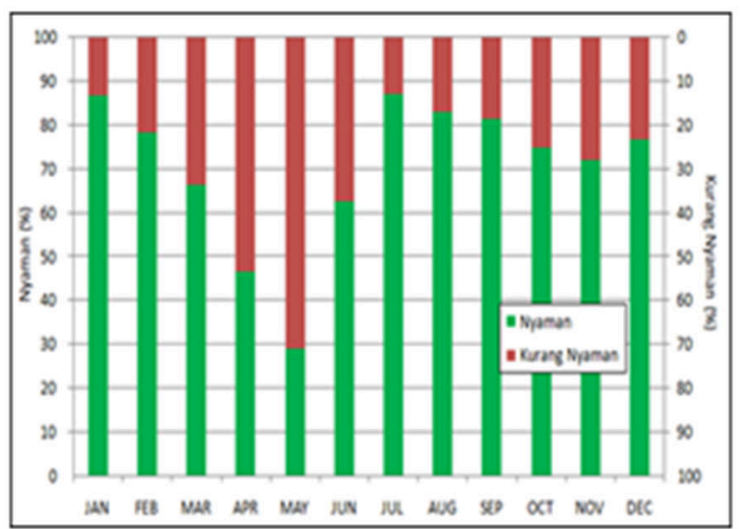

Gambar 2. Grafik persentase kenyamanan bulanan periode $2010-2018$
Pada gambar 2 menyajikan persentase jumlah hari kondisi "Nyaman" dan "Kurang Nyaman" bulanan periode 2010-2018. Pola umum persentase "Nyaman" membentuk lembah terjadi pada bulan Mei. Dari grafik di atas diketahui bahwa lebih dari $60 \%$ jumlah hari pada periode tahun 2010-2018 berada pada keadaan "Nyaman" kecuali pada bulan April dan Mei. Persentase tertinggi terjadi pada bulan Januari, Juli s/d September dan persentase terendah terjadi pada bulan Mei.

Pada tingkat kenyamanan bulanan periode 3 tahunan persentase jumlah hari "Nyaman" lebih rendah dari $50 \%$ berturut-turut terjadi pada bulan April-Mei kecuali bulan April periode tahun 2010-2012 (lihat gambar 3). Keadaan ini serupa dengan gambar 2 yangmana pada April-Mei merupakan persentase kondisi kenyamanan bulanan rendah.

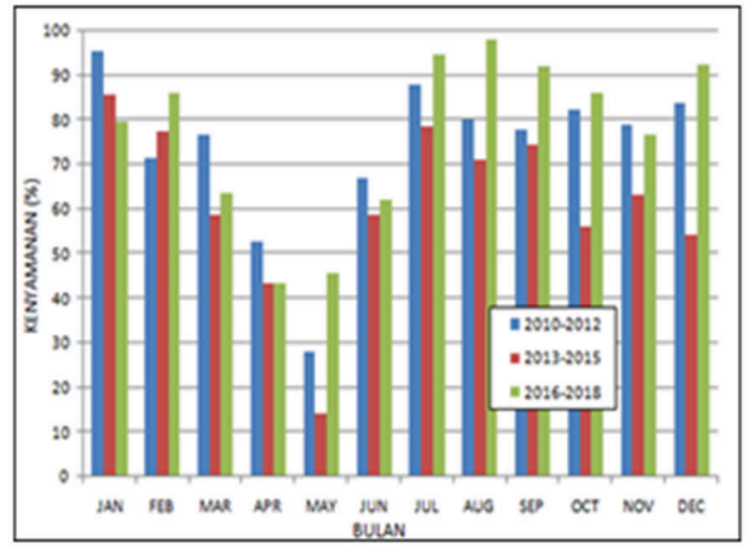

Gambar 3. Grafik persentase tingkat kenyamanan bulanan 3 tahunan periode 2010-2018

Periode tahun 2013-2015 merupakan periode tingkat kenyamanan lebih rendah jika dibandingkan dengan tahun sebelum (20102013) dan tahun sesudahnya (2016-2018). Rendahnya indek kenyamanan periode tahun 2013-2015 tidak lepas dari pengaruh terjadinya bencana kabut asap tahun 2014 dan 2015 seperti yang dikemukakan Sulistiyono dkk. [14] bahwa pada periode terjadi kabut asap tahun 2014 dan 2015 telah menyebabkan kenaikan suhu udara jika dibandingkan dengan suhu pada periode waktu tanpa kabut asap.

Hasil analisis iklim yang dilakukan oleh Panggabean .dkk [15] menjelaskan bahwa pada bulan April-Juni merupakan kondisi suhu rata-rata harian tertinggi di Stasiun GAW Bukit Kototabang dengan puncaknya terjadi pada bulan Mei. Sejalan dengan perhitungan Humidex oleh Trinah Wati dan Riri Indriani Nasution [5] bahwa untuk di wilayah DKI Jakarta pola (suhu) Humidex memiliki 2 puncak mengikuti pola suhu udara. 
Dari analisis tersebut menjelaskan bahwa tingginya rata-rata suhu harian bulan April-Juni di Stasiun GAW Bukit Kototabang menyebabkan penghitungan indek kenyamanan pada kondisi "Nyaman"bulan tersebut lebih rendah dibandingkan dengan bulan-bulan lainnya.

Persentase kondisi “Nyaman" Periode Tahun 2010-2018. Secara umum, persentase jumlah keadaan "Nyaman" dari periode tahun 2010 s/d 2018 masih berada pada kondisi yang baik (> 60\%). Adanya penurunan persentase "Nyaman" pada tahun 2013-2016 disebabkan adanya gangguan dinamika atmosfer seperti aktifnya dipole mode dan sirkulasi atmosfer regional serta adanya peristiwa kabut asap. Adanya gangguan dinamika atmosfer dan kabut asap ini berpengaruh terhadap kenaikan suhu rata-rata harian sehingga menjadikan indek penghitungan kenyamanan menjadi tinggi.

Tahun 2014 merupakan tingkat kenyamanan dengan persentase terendah selama periode tahun 2010-2018 (lihat gambar 4). Hal ini karena pada periode tahun tersebut telah terjadi bencana kabut asap sehingga mempengaruhi suhu udara dan keadaan atmosfer pada saat itu. Persentase tertinggi terjadi pada tahun 2017 dan 2018 dengan masing-masing nilainya sebesar 79.75 dan $83.8 \%$.

Menggunakan dasar persentase indek "Nyaman" tahun 2011 dan 2012 untuk menginterpretasikan keadaan tahun 2017 dan 2018 terkait dengan adanya perubahan kondisi lingkungan sekitar stasiun periode tahun 20102018, didapatkan bahwa belum ada pengaruh dalam hal ini penurunan persentase "Nyaman" dari penghitungan metode Humidex pada tahun 2017-2018.

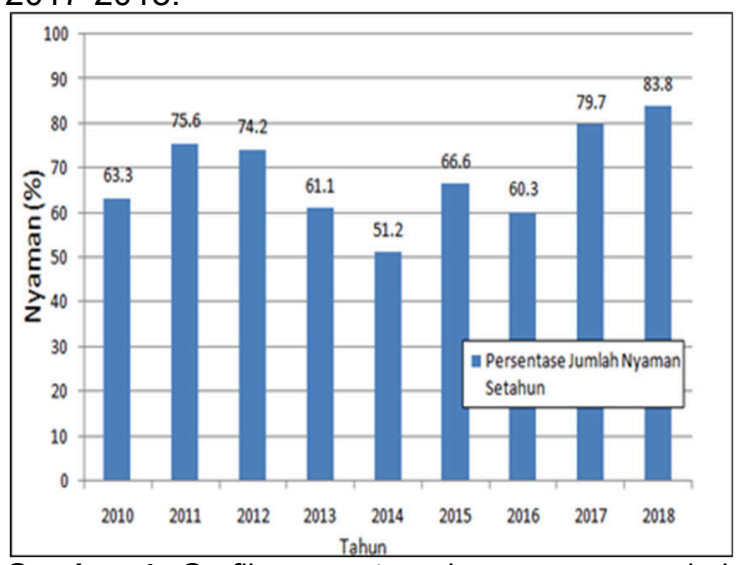

Gambar 4. Grafik persentase kenyamanan periode tahun 2010-2018
Distribusi Persentase “Nyaman" terhadap Persentase Hari Hujan.Pola hujan equatorial dengan 2 puncak hujan (April dan November) terjadi pada grafik jumlah rata-rata hari hujan bulanan Stasiun GAW Bukit Kototabang (lihat gambar 5). Pola umum grafik persentase "Nyaman" bulanan periode tahun 2010-2018 sama dengan pola persentase kenyamanan bulanan periode 3 tahunan yaitu jumlah persentase kenyamanan terendah terjadi pada bulan April-Mei.

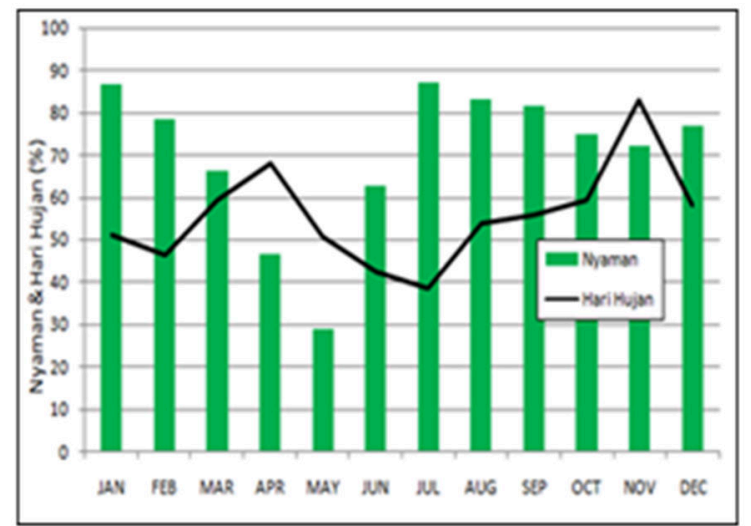

Gambar 5. Grafik Persentase "Nyaman" terhadap jumlah hari hujan periode 2010-2018

Keadaan umum kondisi "Nyaman" bulan April, Juni s/d Juli bertolak belakang dengan jumlah rata-rata hari hujan pada bulan tersebut. Pada bulan April yang merupakan puncak kejadian hujan tetapi jumlah persentase kondisi kenyamanan rendah, sedangkan pada bulan Juni-Juli dengan kondisi kenyamanan tinggi tetapi kejadian hujan pada bulan tersebut kecil. Selanjutnya berbeda halnya pada bulan Oktober-November peningkatan hari hujan bulan itu diimbangi dengan kenaikan persentase kondisi "Nyaman". Hal ini mengindikasikan bahwa keadaan hujan dalam hal ini jumlah hari hujan tidak mempengaruhi secara linier terhadap tingkat kenyamanan di Stasiun GAW Bukit Kototabang. 
Tabel 3.Korelasi Indek Kenyamanan Humidex Terhadap Hari Hujan

\begin{tabular}{|c|c|c|c|c|c|c|c|c|c|c|c|c|}
\hline & $\mid \mathbb{N}$ & 168 & Wh & $A R$ & WAY & WN & Ul & $A \cup O$ & $S 69$ & $\alpha$ & NOV & DEC \\
\hline Vilibi kecelissi & 061 & 0.48 & 091 & 085 & 099 & 0.69 & 0.51 & OE6 & 0.59 & 0.69 & 0.78 & 0.59 \\
\hline Sifathubunean & kest & Qubp & Sonpate & amparkod: & Samparkuat & Qhup & Qhup & Cust & Kust & whop & anetkos? & bust \\
\hline
\end{tabular}

Korelasi Indek Kenyamanan Humidex terhadap Jumlah Hari Hujan. Penghitungan tingkat hubungan (korelasi) antara tingkat kenyamanan Humidex dengan jumlah hari hujan disajikan pada tabel 3. Pada penghitungan korelasi dipilih indek pada kondisi "Nyaman" sebagai penghitungan tingkat hubungan terhadap jumlah hari hujan. Korelasi jumlah hari "Nyaman" tiap bulan terhadap jumlah hari hujan bulanan selama periode tahun 2010-2018 didapatkan nilai rata-rata korelasi tiap bulan sebesar 0.69 yang berarti mempunyai hubungan kuat.

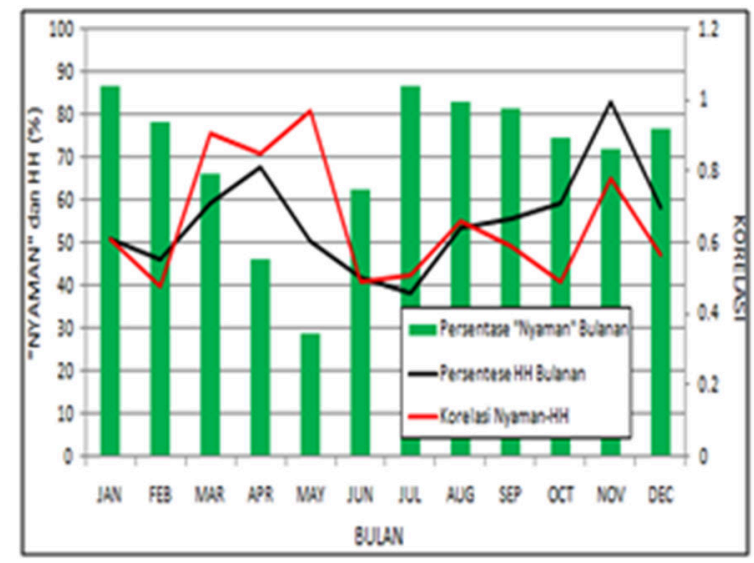

Gambar 6. Grafik korelasi Nyaman- HH terhadap persentase "Nyaman" dan hari hujan

Nilai korelasi tertinggi (sangat kuat) terjadi pada bulan Maret-Mei dan bulan November. Hari hujan yang tinggi pada bulan April tidak membuat persentase "Nyaman" tinggi tetapi sebaliknya pada bulan November dengan tingginya hari hujan sejalan dengan tingginya persentase "Nyaman" saat itu dan bulan tersebut mempunyai korelasi yang sangat kuat. Dari tabel 3 dan gambar 6 menjelaskan bahwa tidak sepenuhnya keadaan hujan dalam hal ini jumlah hari hujan mempunyai hubungan kuat terhadap kondisi "Nyaman" bulanan di Stasiun GAW Bukit Kototabang walaupun secara umum nilai korelasi mengikuti pola jumlah hari hujan bulanan.

\section{Kesimpulan}

Selama periode tahun 2010-2018 penghitungan tingkat kenyamanan metode Humidex stasiun GAW Bukit Kototabang baik hitungan diurnal (periode waktu) maupun harian berada pada kisaran "Nyaman dan "Kurang Nyaman" dan tidak terjadi kondisi 'Tidak Nyaman”.

Selama periode 2010-2018 jumlah persentase terendah kondisi 'Nyaman' terjadi pada tahun 2014 dan tertinggi pada tahun 2017-2018. Berdasarkan hal ini maka persentase "Nyaman" tahun 2017-2018 terhadap tahun 2011-2012 didapatkan bahwa tidak ada perubahan lingkungan yang mengarah pada penurunan tingkat kenyamanan tahun 2017-2018 di wilayah sekitar stasiun GAW Bukit Kototabang.

Korelasi kuat (0.69) antara jumlah kondisi "Nyaman" terhadap jumlah hari hujan bulanan selama periode tahun 2010-2018 tetapi tidak mengapresiasikan secara linier terhadap besaran parameter keduanya.

\section{Daftar Pustaka}

[1] Kalfuadi, Y. (2009). Analisis Temperature Heat Index (THI) Dalam Hubungannya Dengan Ruang Terbuka Hijau. IPB. Bogor.

[2] Talarosha, B. (2005). Menciptakan Kenyamanan Termal Dalam Bangunan. Jurnal Sistem Teknik Industri, 6(3)148158.

[3] Karyono, T.H. (2001). Wujud Kota Tropis Di Indonesia: Suatu Pendekatan Iklim, Lingkungan dan Energi. Jurnal Dimensi Teknik Arsitektur, 44 (2):141-146.

[4] Cahaya Siregar, Diana., Ardah, Vivi Putriama., dan Dara Ninggar, Regina. (2019). Identifikasi Kenyamanan Kota Tanjungpinang Berdasarkan Indeks Panas Humidex. Jurnal IImu Lingkungan, 17(2): 316-322.

[5] Wati, Trinah dan Indriani Nasution, Riri. (2018). Analisis Kenyamanan Termis Klimatologi Di Wilayah DKI Jakarta Dengan Menggunakan Indeks Panas (Humidex). Widyariset, 4 (1): 89-102. 
[6] Wati, Trinah dan Fatkhuroyan.(2017). Analisis Tingkat Kenyamanan Di DKI Jakarta Berdasarkan Indeks THI (Temperature Humidity Index). Jurnal IImu Lingkungan, 15 (1) : 57-63.

[7] Claralampopoulos, loannis., dkk. (2013). Analysis of Thermal Bioclimate In Various Urban Configuration In Athens, Greece. Urban Ecosystems, 16 (2):217-33.

[8] Laly, VE dan BF Watson. (1960). Humitare Revisited. Weatherwise, 13:254-256.

[9] Masterson, J., and F. A. Richardson. (1979). Humidex. A Method of Quantifying Human Discomfort due To Excessive and Humidity. Environment Canada, Downsview, Ontorio.

[10] Spridonov, V., Curie, M., and Zafirovski, O. (2013). Weather and Human Health. COBISS M.K.

[11] Peraturan Kepala BMKG. No 4. (2016). Tentang Pengamatan dan Pengelolaan Data Iklim di Lingkungan Badan Meteorologi, Klimatologi dan Geofisika.

[12] Eka Sas, De. (2016). Batas Waktu Pagi, Siang, Sore Pada Jam. https://wawasan85.blogspot.com/2016/11, diaskses 15 Juli 2019)

[13] Jonathan, Sarwono. (2006). Metode Penelitian Kuantitatif dan Kualitatif. Yogyakarta: Graha IImu.

[14] Sulistiyono, Andi dan Andri, Yosfi. (2017). Respon Radiasi Global dan Suhu Udara pada Peristiwa Kabut Asap Di Stasiun Pemantau Atmosfer. Global Bukit Kototabang. Suara Bukit Kototabang, 9 : 18-25.

[15] Panggabean, Manat et all. (2017). Analisis Iklim Stasiun GAW Bukit Kototabang. Suara Bukit Kototabang, 9 : 11-17. 